\title{
ISLAMIC GOLD DINAR: THE HISTORICAL STANDARD
}

\author{
Ahamed Kameel Mydin Meera ${ }^{1}$
}

\begin{abstract}
Lately, there have been questions on what the standards for gold dinar and silver dirham should be. Since the dinar and dirham indeed formed the Shari'ah monetary standards from the time of the Prophet pbuh, our work can, therefore, only involve in the rediscovery of that classical standard. Henceforth no parties or organizations can come up with their own standards. Since the Islamic gold dinar $^{2}$ did not come into existence until about 50 years after the Prophet's pbuh demise, it is obvious from history that the solidus of the Eastern Roman Byzantine Empire was the monetary basis for the Shari'ah. Hence the best way to determine the standard is to look at the definition given by its issuer, the Byzantine Empire. Coins unearthed by archeologist cannot be relied upon for this purpose because such coins generally suffer from wear and possible tempering like clipping etc. It was found that the actual historical standard for the dinar to be $4.5 \mathrm{gm}$ of pure gold and the dirham to be $3.15 \mathrm{gm}$ of pure silver. However, since the role of dinar is simply as a measure of value that depends on the goldcontent of the coin and if zakat is based upon 1-year's provision of foodstuff and not the physical weight of dinars, then the $4.25 \mathrm{gm}$ dinar of pure gold and $2.975 \mathrm{gm}$ dirham of pure silver, as those circulated during the Prophet's pbuh era, is the standard since the Prophet had said, "The system of weights and measures is the system of the people of Medina."
\end{abstract}

Keyword: Gold Dinar, History of the Gold Dinar, Standard Weight

\footnotetext{
${ }^{1}$ International Islamic University Malaysia, Email: akameel@gmail.com

${ }^{2}$ Islamic in the sense the pagan inscriptions on the dinar and dirham were replaced with inscriptions based on verses from the Holy Qur'an.
} 


\section{INTRODUCTION}

Undoubtedly, the interest in gold dinar among the public, academics, business community and even governments has increased lately. The turmoil in the US and Europe and the ongoing global economic and monetary crisis has added to this interest. Capitalism based on interest-based fiat monetary system is indeed collapsing and the world is on the lookout for possible solutions to the crisis. Returning back to gold as the international monetary standard has been one suggestion from some quarters. In the case of Islamic economics, the call is to go back to the Islamic gold dinar that was the monetary standard of Shari'ah throughout Islamic history till the fall of the Ottoman Caliphate in 1924. The gold dinar is generally agreed upon as a $4.25 \mathrm{gm}$ gold coin, based upon the average weight of the Roman solidus that circulated during the times of the Prophet pbuh. Muslims did not have their own coinage during the time of the Prophet pbuh. The gold dinar forms the monetary standard for the Shari'ah rulings on muamalat, zakat, hudud and mahr. Nonetheless, there are differences in opinion among today's proponents of gold dinar on the purity and weight of the coin - Should it be made of $22 \mathrm{~K}$ gold or $24 \mathrm{~K}$ fine gold? Should it be $4.25 \mathrm{gm}$ or more than that? Twenty four karat (24K) gold is fine gold, by today's standard it is 99.99 percent pure. The $22 \mathrm{~K}$ accordingly contains $91.66 \%$ gold $^{3}$, hence known as 916 gold. Due to the rounding, some gold dealers make it to be 917 , which means that in one thousand parts, 917 parts is gold while the rest is some other metals, normally silver or copper.

The question whether the gold dinar is of fine gold or not is important because it is the Shari'ah standard and even the zakat, the fifth pillar of Islam, is based on it. The nisab for money is 20 dinars. One who had twenty dinar in one's possession for one year will have to pay a $2 \frac{1}{2} \%$ zakat on it, i.e. half-dinar.

The objective of this paper is to determine using historical facts the standards for the dinar and dirham. Section 2 of this paper looks at the early history and functions of the gold dinar in Muslim society. Section 3 attempts to determine the historical standards of the dinar and dirham. Section 4 looks at the softness pure metal coins and the issue of tear and wear, while Section 5 briefly discusses the inscriptions on the dinars and dirhams. Section 6 discusses the issue of zakat on dinar and dirham. Section 7 discusses the modern implementation of the dinar while Section 8 concludes.

\section{Brief History and Functions of the Gold Dinar}

\footnotetext{
${ }^{3} 22 / 24$ gives 91.6666 .
} 


\subsection{History of the Gold Dinar During the Prophet's Era in Medina}

At the time of the Prophet pbuh in the early $7^{\text {th }}$ Century, the Muslims did not mint the gold dinars or silver dirhams yet. The Prophet pbuh accepted the Roman Byzantine gold solidus, also known as the bezant, and the Persian Sassanid Empire's silver dirham as the monetary standards for Muslims. In this is wisdom because these coins enabled just trade among Muslims and with non-Muslims as well. It was these coins that circulated among the Arabs for decades before the Muslims minted their own coins. The Prophet would have not accepted if these were not of Islamic in nature, i.e. they promote the maqasid al Shari'ah. This bimetallism also has to be a standard that was just and stable; and facilitate trade and business even among Muslims and non-Muslims. The first Islamic gold dinars were, however, not minted until about half century after the demise of the Prophet pbuh, by the fifth Umayyad caliph Abd al-Malik ibn Marwan, in the year $75 \mathrm{H}(697 \mathrm{CE})$.

Since the gold coin of the Eastern Roman Byzantine Empire, the solidus, was the coin accepted by the Prophet pbuh and that circulated among the Muslims, it is this coin we need to research and understand. Surely the Islamic gold dinars minted much later by the Muslim rulers must follow this standard. Before we go to this, let's look at the purpose and functions of the gold dinar.

\subsection{Function of the Gold Dinar}

The gold dinar played the role of money in Islam. Hence it eliminated problems generally associated with barter trades, like double coincidence of wants and the problem of divisibility. However, as money, it also enabled people to specialize in whatever they did best and hence increased their productivity, output and trade; and thereby increased the standard of living of the people. Hence among the most important function of the gold dinar as money was as a stable measure of value. By this, people are able to exchange goods and services in a just manner and able to save for future consumption and investments, transact in credit and repay debt in future. Al Ghazzali and Ibn Khaldun rightly asserted that Allah SWT created gold and silver as measure of value. Hence gold and silver are the standards by which the values of all things are measured.

Indeed, the current global monetary system that is based on fiat money has this stable measure of value missing since the collapse of the Bretton Woods in 1971. Hence the system is devoid of a numeraire or an anchor that links the monetary sector to the real economy. We would assert this as the fundamental reason for the current collapsing of Capitalism. 
When anything is taken as a standard of measure, it has to be 'pure' and simple so that people can easily relate to it. Length, for example, is measured by kilometer. A kilometer is defined as the distance travelled by light in vacuum in 1/299792.458 second. The kilogram on the other hand is defined as the base unit of mass in the International System of Units and is defined as being equal to the mass of the International Prototype Kilogram (IPK), which is almost exactly equal to the mass of one liter of water ${ }^{4}$. Since international trade and business involves exchange of goods and services, what the world needs today is a stable measure of value against which the value of all things can be measured.

\section{DETERMINING THE STANDARDS FOR DINAR AND DIRHAM}

\subsection{The Purity of the Islamic Dinar and Dirham}

This question should not be difficult to answer because the gold dinar had been a historical standard among Muslims for centuries. It is not a modern innovation or theoretical construction.

The Prophet pbuh is reported to have said: The system of weights and measures is the system of the people of Medina (Sahih Bukhari).

Hence to answer the question on the purity of the gold dinar, one simply has to go back to history, particularly the time of the Prophet Muhammad pbuh. Since the gold dinar that circulated among the Arabs was the solidus of the Roman Byzantine Empire, we shall look into its history first.

\subsection{The Roman Aureus and Solidus}

The Roman gold coin, the aureus, was among the earliest Roman gold coins, issued from the 1 st century $B C$ to the beginning of the 4th century. The aureus of Julius Caesar was struck 40 to the Roman libra pound. The libra pound is about $327.4 \mathrm{gm}$. Hence, the coin weighed about $8 \mathrm{gm}$. Later, the emperor Nero reduced the weight of the aureus by minting it 45 to the pound, i.e. about $7.3 \mathrm{gm}$. The aureus was then replaced by the solidus that was first introduced by Diocletian around $301 \mathrm{AD}$, struck at 60 to the Roman pound of pure gold, weighing about $5.5 \mathrm{gm}$ each. Due to its limited quantity its economic effects were minimal. Hence, the solidus was reintroduced by Constantine I in 312 AD, permanently replacing the aureus as the official gold coin of the Roman Empire. The solidus of Constantine was struck at a rate of 72 to a Roman Byzantine pound (litra) which

\footnotetext{
${ }^{4}$ The IPK is made of a platinum-iridium alloy and is stored in a vault at the International Bureau of Weights and Measures in Sèvres, France. However, the weight of this alloy has been changing over time, and hence the call for a redefinition of the kilogram.
} 
equals 324gm, each coin weighing twenty-four Greco-Roman carats, or about 4.5 grams of pure gold per coin. Analysis of the Roman aureus and solidus, regardless of the size or weight, shows the purity level to be near 24 carat gold in excess of 99\%. Whenever the coin was taken in by the treasury, it was melted down and reissued. This maintained the evenness of the weight of the circulating solidi ${ }^{5}$.

Hence it is obvious that the gold dinars of the Roman solidus that circulated among the Arabs during the advent of the Prophet pbuh were of fine gold, exceeding 99 percent purity. However, since the solidi circulating outside the Roman Empire were not used to pay taxes to the emperor they did not get reminted, and hence the soft pure-gold coins became quickly worn ${ }^{6}$. Hence, the average weight of the coins in the Arab world was about $4.25 \mathrm{gm}$, from the original weight of $4.5 \mathrm{gm}$. Regarding the first dinar coins minted by the Muslims, Bernstein said the following:

Less than fifty years after the death of Prophet Muhammad (peace be upon him), the Arabs emulated the great rulers of the past with the debut of their own gold coinage - the dinar - issued by the Caliph Abd alMalik at Damascus in $75 \mathrm{H}$. These coins, 97 percent pure gold and minted in great quantity gradually displaced the bezant as the major international currency, circulating throughout the Arab domains and everywhere in Christian Europe as well?

One could attribute this slightly lower purity of the first Islamic gold dinar, i.e. $97 \%$, compared to the Roman coin to the fact that this was the first attempt of Muslims to mint their own coins and hence their relative inexperience in the refining and minting technology compared to the Romans who had been doing this for centuries. However, undoubtedly the intention was to get a coin as pure gold as possible. Historical evidences show that by the time of the Fatimid Dynasty in Egypt, dinars of fine gold were already in circulation ${ }^{8}$.

\subsection{The Standard Weight of the Islamic Gold Dinar}

\footnotetext{
${ }^{5}$ Wikipedia

${ }^{6}$ Porteous, John (1969). "The Imperial Foundations". Coins in history : a survey of coinage from the reform of Diocletian to the Latin Monetary Union.. Weidenfeld and Nicolson. pp. 14-33

${ }^{7}$ Bernstein, The Power of Gold - The history of an obsession, p67.

${ }^{8}$ All dinars are indeed of pure gold but constrained by mining and refining technologies of the time. By the Fatimid period Muslims seem to have perfected the technology; something the Romans had known much earlier.
} 
It was reported on the authority of Jabir that the Prophet pbuh said, "The weight of the dinar is 24 qirats" 9 . Also Ibn Khaldun asserted the following in alMuqaddimah:

Know that there is consensus since the beginning of Islam and the age of the Companions and the Followers that the dirham of the shari'ah is that of which ten weigh seven mithqals weight of the dinar of gold... The weight of a mithqal of gold is seventytwo grains of barley, so that the dirham which is seven-tenths of it is fifty and two-fifths grains. All these measurements are firmly established by consensus.

The statement by Ibn Khaldun implies that once we determine the weight of either the dinar or the dirham, the weight of the other can be determined automatically.

Hence, determining the standard weight should be easy but rather challenging. Easy because we are dealing with something that had existed historically, and not developing a theoretical one. One cannot totally rely on coins unearthed by archeologist in this regard because unearthed coins generally would have experienced some tear and wear depending on how long they had been in circulation and also due to some variance in the weight of individual coins themselves. Some could have been tempered through clipping and so forth. Hence it is best we resort to the definition of the coins as determined by the issuing authorities, like in this case the Roman Byzantine Empire.

It is obvious that the Islamic gold dinar is based on Constantine's Roman solidus which was struck 72 to the Roman Byzantine pound (litra) used for gold measurement. The litra pound is recorded to be $324 \mathrm{gm}$, which gives an ounce to be $27 \mathrm{gm}^{10}$. Hence the weight of the solidus is $4.5 \mathrm{gm}$ as recorded, equals one mithqal, equals 24 Greco-Roman carats ${ }^{11}$. This coin was frequently melted down and reminted to preserve the weight. However, as mentioned earlier, the coin circulated among the Arabs with an average weight about $4.25 \mathrm{gm}$ due to tear and wear. Coins of the time of Abd al-Malik ibn Marwan, unearthed by

\footnotetext{
${ }^{9}$ Qirat is carat. In today's jargon, 24K is also used to denominate pure gold.

${ }^{10} 27 \mathrm{gm}$ was the old Roman-Byzantine ounce from which the original solidus standard had been derived. See Timothy Garrard, Akan Weights and the Gold Trade, London 1980, p215.

${ }^{11}$ Traditionally, 1carat (the mass of a carob seed) equaled the weight of 3 barley grains or 4 wheat grains.
} 
archeologists, have the weight of the dinar at about 4.25 grammes $^{12}$, matching the weight of the worn solidi that circulated in those areas. Therefore the actual mithqal or dinar should weigh 4.5gm of pure gold. However, as the Islamic empire expanded and trade flourished, it must have become apparent that the gold dinar was less in weight compared to the Roman solidus ${ }^{13}$. The Caliph Umar ibn Abd al-Aziz is said to have alerted that the dirhams of Abd al-Malik ibn Marwan were at 7:10.5 to the mithqal instead of the standard at 7:10. Hence he corrected the matter and issued, in $99 \mathrm{H} / 717 \mathrm{CE}^{14}$, silver dirhams and gold dinars of weight $3.15 \mathrm{gm}^{15}$ and $4.5 \mathrm{gm}$ respectively, i.e. similar weigh to the Roman solidus, i.e. $4.5 \mathrm{gm}^{16}$.

From the above mentioned hadith and historical facts, it can be established that the Islamic dinar is of pure gold which equals one mithqal or 24 girats or 72 grains of barley, that equals $4.5 \mathrm{gm}$ in modern weight. Accordingly, a barley grain weighs $0.0625 \mathrm{gm}(4.5 \mathrm{gm} \div 72)^{17}$, i.e. $62.5 \mathrm{mg}$. See Table 1 below. Also well-known is the fact that 7 mithqals equal in weight to 10 dirhams. Therefore, this also implies that the silver dirham is of pure silver, weighing $3.15 \mathrm{gm}(0.7 \times 4.5 \mathrm{gm})$ that equals $50 \frac{2}{5}$ grains $(3.15 \div 0.0625$ or $0.7 \times 72)$ as mentioned by Ibn Khaldun.

\footnotetext{
${ }^{12}$ Subhiì, 1976: p427

${ }^{13}$ The Roman Byzantine Empire lasted till 1416 CE. However, the Persian Sassanid Dynasty that was responsible for the silver dirham that circulated among the Arab, ended much earlier around 644CE.

${ }^{14}$ Kitab Adh-Dharaib fi as Sawad, p65 as referenced in http://islamhariini.wordpress.com

${ }^{15} \mathrm{Abd}$ al-Malik's dirham was close to $3 \mathrm{gm}$, but the Roman solidus weighed $4.5 \mathrm{gm}$. Hence Umar ibn Abd Aziz's remark of the ratio 7:10.5, i.e. $\frac{7}{10.5}=\frac{3}{4.5}$

${ }^{16}$ Archeological gold dinars of this period weighed in the range $4.4 \mathrm{gm}$ to $4.6 \mathrm{gm}$. To what weight he corrected the dirham and the dinars depends on what standard dinar he was comparing the dirhams to. We contend it must be the Roman solidus, that weighed $4.5 \mathrm{gm}$.

${ }^{17}$ This weight of a barley grain is computed based on the above statement by Ibn Khaldun. Barley grains do vary in weight, that is subject to change due to moisture content etc. The International Systems of Units set the barley grain as equal to $0.06479891 \mathrm{gm}$
} 
Table 3.1

Gold Weights in Roman and Eastern Byzantine Empire

\begin{tabular}{|l|c|}
\hline \multicolumn{1}{|c|}{ Roman Empire } & Weight \\
\hline Roman libra (pound) & $327.4 \mathrm{gm}$ \\
\hline Troy grain & $0.06479891 \mathrm{gm} *$ \\
\hline Grains in one Roman pound & 5053 grains \\
\hline Aureus of Julius Caesar 1/40 & 8.185gm (126.31 grains) \\
\hline Aureus of Nero 1/45 & 7.2756 gm (112.28 grains) \\
\hline Solidus of Diocletian 1/60 & 5.4567 gm (84.21 grains) \\
\hline 1 qirat (carat) & $324 \mathrm{gm}$ \\
\hline Byzantine Empire 476AD \& Islamic Caliphate & $0.0625 \mathrm{gm} * *$ \\
\hline Byzantine litra (pound) & 5184 grains \\
\hline Barley grain & $4.5 \mathrm{gm}$ (72 grains) \\
\hline Grains in one Roman pound & $0.1875 \mathrm{gm}$ \\
\hline Solidus of Constantine I 1/72 & $4.5 \mathrm{gm}$ (72 grains) \\
\hline 1 qirat (carat) - 3 barley grains & \\
\hline 1 dinar (mithqal) - 24 qirat & \\
\hline
\end{tabular}

*This definition of troy grain was established in 1958 in terms of units of mass in the International System of Units

**Computed based on Ibn Khaldun's statement that there are 72 barley grains in one mithqal that also equals 24 Greco-Roman carats.

\section{SOFTNESS OF 24K GOLD DINARS AND THE ISSUE OF TEAR AND WEAR}

The original gold dinar and silver dirham were made from pure gold and pure silver respectively. In the pure form they are soft and therefore can get worn in the process of circulation. Nonetheless, gold and silver have the highest ductility and malleability among all metals ${ }^{18}$. The atoms of these metals are strongly

\footnotetext{
${ }^{18}$ Ductility is a solid material's ability to deform under tensile stress, i.e. the material's ability to be stretched into a wire. Malleability is a material's ability to deform under compressive stress, i.e. the material's ability to form a thin sheet by hammering or rolling. Both of these mechanical properties are aspects of plasticity, the extent to which a solid material can be plastically deformed without fracture [Wikipedia].
} 
bonded among them but however can move easily around them. Therefore even though the gold and silver coins can become worn in the process of circulation, the process is not easy though and rather is slow.

To address this issue of tear and wear, the Roman empire, as mentioned earlier, would melt down and remint the coins it receives as tax in order to maintain the standard weight of 4.5 grams.

Some quarters assert that the dinar should not be of pure gold since it would easily get worn out. They say that in about 3 years the coins may lose enough gold to be rejected as dinar. However, the Roman solidus that was circulating, for decades, outside the Roman empire had a weight of about 4.25 grams $^{19}$ and for decades people did accept them as dinars, without ever being recalled or being reminted since the Islamic coinage only began in $75 \mathrm{H}$. It is our contention that the Islamic government, as the Roman empire, should continuously remint the coins to preserve the weight of the coins.

\section{INSCRIPTIONS ON THE ISLAMIC GOLD DINAR}

Generally, the Islamic gold dinar does not depict pictures of caliphs, rulers, animals or other living things in accordance with Shari'ah that discourages such practice. The first Islamic gold dinar, i.e. that of Abd al-Malik ibn Marwan, had inscriptions based on Quranic verses. One could notice that the earliest coins never had full Qur'anic verses on them. Perhaps this is because the early learned scholars could have opined that it is highly possible for people to bring coins into impure places like toilets and so forth; and also possible to lose them to the ground. Also because coins pass from hand to hand in circulation, one cannot afford to make a mistake in Qur'anic verses inscribed on the coins. Once circulated it would be extremely difficult to call them back, in case of mistakes.

For example the dinar and dirham of Abd al-Malik ibn Marwan had the following inscriptions: The obverse of the coin has as its central legend the Kalima Shahada, i.e. "There is no god except Allah alone, there is no partner with Him'. Around it, is the mint date formula reading "In the Name of Allah. This dirham was struck in the year $79 \mathrm{AH}$ ". The reverse of the coin has the central inscription based on Surah 112 of the Quran: "Allahu Ahad, Allahu-Samad, Lam Yalid wa lam Yulad wa lam Yakul-lahu Kufu-an Ahad"'. The marginal legend is based on Surah 9, Taubah Verse 33. It states: "Muhammad is the Messenger of Allah, he was sent with

\footnotetext{
${ }^{19}$ That is a loss of about $5.5 \% \mathrm{t}$, but we are not sure for how long the coins circulate before losing that much.
} 
guidance and the religion of truth to make it prevail over every other religion." Note that these are not full Qur'anic verses.

\section{Zakat on the Dinar and Dirham}

It is important to note that the basis for the Prophet pbuh fixing the nisab for silver at 200 dirhams and the nisab for gold at 20 dinars was that either of these two sums represented, in Prophet's day, the market price of 5 camel-loads of grain or, in other words, of one year's provision of essential food-stuffs for an average family. Accordingly, the value of one dinar during the prophet's time was equal to 10 dirhams. Hence the basis for the nisab was not the physical count of the dinar but rather the purchasing power of the money ${ }^{20}$.

Hence it may not matter whether the dinar is $22 \mathrm{~K}$ or $24 \mathrm{~K}$ because the value of each will be based on their respective gold content. Henceforth, the nisab for silver and gold must be established on the same basis as practiced by the prophet pbuh, i.e. on the proportionate value of the year's provision of essential foodstuffs in relation thereto, as dictated by the prevailing market price. Therefore, nisab for gold and silver must vary from year to year in conformity with the price fluctuations of essential food grain ${ }^{21}$.

\section{The Modern Implementation of the Islamic Gold Dinar}

When the gold dinar gets implemented in the modern world, it would surely rely heavily on information and communications technology (ICT), particularly the internet. Gold-based interest-free electronic credit is the most desirable form of money (using cards, internet, mobile phones, computers etc). Here, the gold dinar would predominantly play the role as measure of value that involves only the recordings of credit transactions that are periodically net-off. Such system is not akin to fractional reserve banking because this system does not create new money and does not involve the transfer of credits for payment purposes. Accordingly, the need for physical dinars will be much minimized. The periodic settlements can be done using even gold bars and not necessarily using gold dinar coins. Also the system permits real-time electronic audits.

Such electronic interest-free money is desirable because it fully takes advantage of the concept of money as a measure of value, i.e. as a means for keeping score. Hence practically there will be no situations of shortage of money that can plunge an economy into recession and thereby give hoarders of money the advantage to

\footnotetext{
${ }^{20}$ Roy Jastram proved that price of things relative to gold are relatively constant over long periods of time. See his book The Golden Constant.

${ }^{21}$ Zayas, Farishta G. de, The Law and Institution of Zakat, The Other Press, 2003, p74.
} 
charge interest on borrowings. Since the system does not create new money, it will not create inflation.

Diagram 7.1

Historical Time-Line

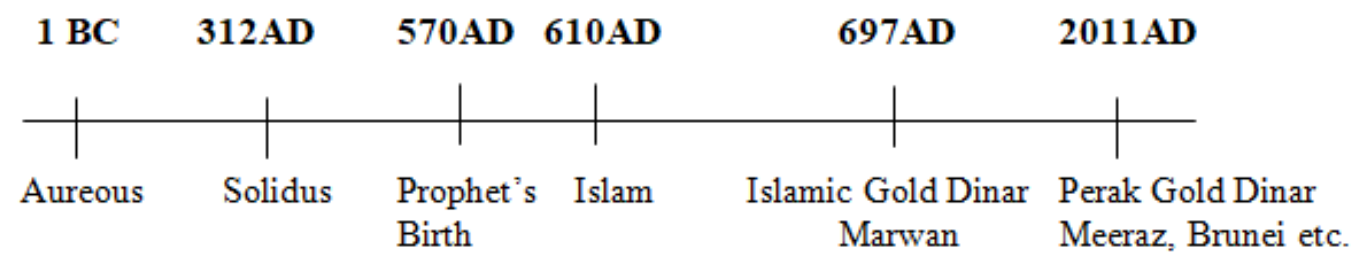

\section{Conclusion}

The words dinar and dirham are mentioned in the Qur'an. These precious metals are to play the role of measure of value for just economic and business transactions. As Islam is pure, its measures of value must be pure too. Pure makes it easier for standardization for all nations and people, without ambiguity, forex risk; simply a pure reference point, an anchor, a numeraire.

But as for all who lay up treasures of gold and silver and do not spend them for the sake of Gods - give them the tiding of grievous suffering [in the life to come]:

Qur'an, Surah Taubah, 9:34

As Allah SWT mentions gold and silver in the above verse in the context of money, we read that He means pure gold and pure silver and not with impurities added, like the 917 gold that some quarters asset as the standard for the dinar.

Hence, with simple deductions using historical facts, we ascertained that the original standard for dinar and dirham are $4.5 \mathrm{gm}$ of pure gold and $3.15 \mathrm{gm}$ of pure silver. However, the popular standard that is being adopted in most of the Muslim world is the Abd al Malik ibn Marwan standard of $4.25 \mathrm{gm}$ of gold, hence the nisab for gold being $85 \mathrm{gm}$. Therefore to keep things simple we come to the conclusion that any pure gold coin having the weight between $4.25 \mathrm{gm}$ to $4.5 \mathrm{gm}$ may defined as dinar. The exchange rates between the dinars would be purely based on the gold content in the alloy coin.

In the present time, however, we cannot mint a coin inferior to that of Abd al Malik ibn Marwan. It was clear Muslims strived to get coins as pure as possible. 
Hence the WIM standard of $4.25 \mathrm{gm}$ of 917 gold seems erroneous because the coins would have less gold than the historical standard.

The use of $22 \mathrm{~K}$ dinars would lower the nisab ${ }^{22}$ and if people were to pay zakat on it, I guess they would not be punished for lowering the hurdle, but nonetheless $24 \mathrm{~K}$ is the standard The value of the $22 \mathrm{~K}$ will be based on the pure gold content of the coin, anyway.

However, it may be trivial to argue whether the gold dinar is $22 \mathrm{~K}$ or $24 \mathrm{~K}$ since the gold content will determine their respective value, play the role of measure of value. And if the basis for payment of zakat is based upon one-years' provision of food-stuff, it becomes immaterial whether the gold dinar is $22 \mathrm{~K}$ or $24 \mathrm{~K}$. However, in most parts of the world the zakat is computed based on weight, i.e. the nisab of 20 dinar.

Nontheless, for defining the dinar standard for gold exchange purposes, we propose $4.25 \mathrm{gm}$ of 999 gold. $4.25 \mathrm{gm}$ since that is the popular definition today; and 999 gold because to convert 999 gold to 9999 gold the cost is high and involves chemicals that can harm the environment. Accordingly the exchange standard for dirham is $2.975 \mathrm{gm}$ of 999 silver.

Islam as inherited by Muslims from the Prophet pbuh is a complete religion. As the following verse from the Holy Qur'an asserts.

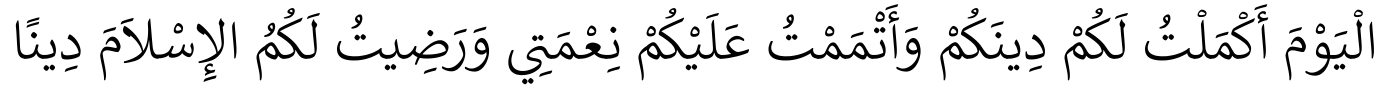

Al-Maidah, 5:3

This day have I perfected your religion for you, completed My favour upon you, and have chosen for you Islam as your religion

Being a religion that is complete without defects or shortcomings, it needed no human efforts to perfect it, solve or rectify any shortcomings.

Also, since the Prophet pbuh said that the system of measure is the system of Medina, we contend that it should be perfectly alright to mint the Islamic gold dinar according to that of the time of the Prophet pbuh i.e. a 24K (999 purity) gold coin of 4.25 grams in weight and the dirham of $2.975 \mathrm{gm}^{23}$ of fine silver $(999$ purity). Also since modern electronic payment systems are likely to be the way forward, the $24 \mathrm{~K}$ fine gold should be the basis of the monetary standard.

\footnotetext{
${ }^{22}$ If zakat is calculated based on weight, i.e. 20 dinars.

${ }^{23}$ For the convenient of the people it could be made $3 \mathrm{gm}$ since the difference is negligible.
} 


\section{Reference}

Bernstein, Peter L., The Power of Gold - The history of an obsession, John Wiley, 2000

Ibn Khaldun, al-Muqaddimah - An Introduction to History, trans. Franz Rosenthal, Princeton University Press, 1958.

Porteous, John (1969). "The Imperial Foundations". Coins in history : a survey of coinage from the reform of Diocletian to the Latin Monetary Union. . Weidenfeld and Nicolson.

Subhì, Salih (1976). al-Nuzum al-Islamiyya (Islamic Systems). Beirut: Dar al-Alim Kitab Adh-Dharaib fi as Sawad

Hunwick, John, Islamic Financial Institutions: Theoretical Structures and Aspects fo the Application in Sub-Saharan Africa, in Credit, Currencies and Culture - African Finanical Institutions in Historical Garrard Perspaectiv, Ed. Endre Stiansen and Jane I. Guyer, Elanders Gotab, Sweden, 1999. P86

Timothy, Akan, Weights and the Gold Trade, London 1980, Jastram, Roy, The Golden Constant,, John Wiley, 1977. 
This page is intentionally blank 